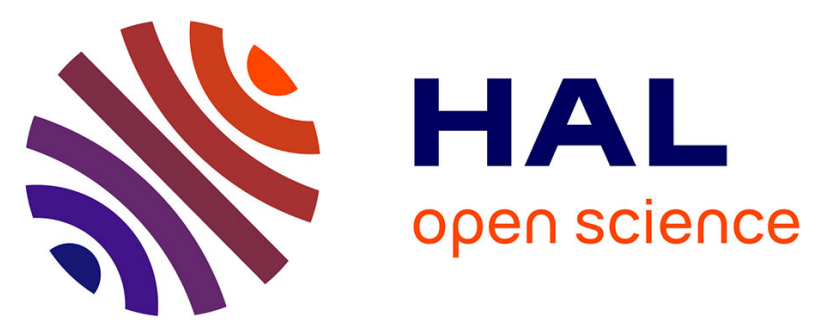

\title{
Musculoskeletal injuries among operating room nurses: results from a multicenter survey in Rome, Italy
}

Umberto Moscato, Daniela Trinca, Maria Luisa Rega, Alice Mannocci, Giacomina Chiaradia, Giovanni Grieco, Walter Ricciardi, Giuseppe La Torre

\section{- To cite this version:}

Umberto Moscato, Daniela Trinca, Maria Luisa Rega, Alice Mannocci, Giacomina Chiaradia, et al.. Musculoskeletal injuries among operating room nurses: results from a multicenter survey in Rome, Italy. Journal of Public Health, 2010, 18 (5), pp.453-459. 10.1007/s10389-010-0327-9 . hal-00521156

\author{
HAL Id: hal-00521156 \\ https://hal.science/hal-00521156
}

Submitted on 26 Sep 2010

HAL is a multi-disciplinary open access archive for the deposit and dissemination of scientific research documents, whether they are published or not. The documents may come from teaching and research institutions in France or abroad, or from public or private research centers.
L'archive ouverte pluridisciplinaire HAL, est destinée au dépôt et à la diffusion de documents scientifiques de niveau recherche, publiés ou non, émanant des établissements d'enseignement et de recherche français ou étrangers, des laboratoires publics ou privés. 
Editorial Manager(tm) for Journal of Public Health Manuscript Draft

Manuscript Number: JOPH-D-09-00043R3

Title: Musculoskeletal injuries among the operating room nurses: results from a multicenter survey in Rome, Italy.

Article Type: Original Article

Corresponding Author: Prof. Dr. Giuseppe La Torre,

Corresponding Author's Institution: Sapienza University of rome

First Author: Giuseppe La Torre

Order of Authors: Giuseppe La Torre

Abstract: Background

Chronic disorders of the musculoskeletal system, particularly low back pain (LBP), are increasing and represent a social and economical problem of growing importance, especially if correlated with working conditions. Healthcare workers are at higher risk to develop LBP during the work-shift in hospital. Aim of this study was to assess the prevalence of LBP among operating room nurses and to investigate the risk factors for musculoskeletal injuries in the operating rooms.

Methods

We carried out a cross-sectional study, which included operating room nurses from nine hospitals. Information on socio-demographic characteristics, life-style habits, working activity and psychological attitude of nurses was collected using an anonymous self-administered structured questionnaire. We evaluated the association of Frequency, Localization and Intensity of LBP (FLI) with qualitative variables making use of the univariate analysis, chi-square test and Fisher's Exact test. Multiple logistic regression analysis was performed to identify the variables that affected the FLI. The covariates included in the model were the variables that had a $\mathrm{p}<0.25$ to the univariate analysis. The significant level was fixed at $\mathrm{p}<0.05$.

Results

We studied a total of 185 (60.5\% male) operating room nurses with a mean age of 36.08 (SD=7.08). The chi-square test showed that FLI is associated with age ( $\mathrm{p}=0.042)$, physical activity ( $\mathrm{p}=0.036)$, and work-shift $(\mathrm{p}=0.01)$. The logistic regression indicated that age $>35$ years vs. age $<35$ (OR=2.68; 95\% $\mathrm{CI}=1.17-6.18)$ and diurnal work-shift vs. diurnal/nocturnal $(\mathrm{OR}=4.00 ; 95 \% \mathrm{CI}=1.72-9)$ represent risk factors associated to FLI, while physical activity is a protective factor $(\mathrm{OR}=0.47 ; 95 \% \mathrm{CI}=0.20-1.08)$. Discussion

The data suggest that it is important to promote new programmes of prevention based on professional training and physical activity among nurses and to improve the organisation of work-shift in hospital.

Response to Reviewers: Dear Prof. Kirch,

Many thanks to the reviewer for his/her valuable suggestions.

We made the changes requested, i.e.: 
In the third section of "Results" (p. 6, line 29 - 40), we correctyed the orthographic mistakes:

- line 31/32: vs must be vs.;

- $\mathrm{p}=0,014$ instead than $\mathrm{p}=00,14$

- Moreover, wwe used the same spelling in the whole text for the "p" values: XXX=XXX (without blanks before and after the "=")

Many thanks for the opportunity to consider our work for publication on the Journal of Public Health 
Musculoskeletal injuries among the operating room nurses: results from a multicenter survey in Rome, Italy.

Umberto Moscato ${ }^{1}$, Daniela Trinca ${ }^{2}$, Maria Luisa Rega ${ }^{1}$, Alice Mannocci ${ }^{1}$, Giacomina Chiaradia $^{3}$, Giovanni Grieco ${ }^{1}$, Walter Ricciardi ${ }^{1}$, Giuseppe La Torre ${ }^{4}$

${ }^{1}$ Institute of Hygiene, Catholic University of Sacred Hearth, Rome, Italy

${ }^{2}$ Hospital Unit "San Giovanni di Dio", Rome, Italy

${ }^{3}$ National Institute of Infectious Diseases “L. Spallanzani”, Rome, Italy

${ }^{4}$ Clinical Medicine and Public Health Unit, Sapienza University of Rome, Italy

Giuseppe La Torre

Clinical Medicine and Public Health Unit,

Sapienza University of Rome,

Viale Regina Elena 324

00185 - Rome, Italy

Tel. +39-06-49970388

e-mail: giuseppe.latorre@uniroma1.it 


\section{ORIGINAL ARTICLE}

Musculoskeletal injuries among the operating room nurses: results from a multicenter survey in Rome, Italy. 


\section{Summary}

Aim Chronic disorders of the musculoskeletal system, particularly low back pain (LBP), are increasing and represent a social and economical problem of growing importance, especially if correlated with working conditions. Healthcare workers are at higher risk to develop LBP during the work-shift in hospital. Aim of this study was to assess the prevalence of LBP among operating room nurses and to investigate the risk factors for musculoskeletal injuries in the operating rooms.

Methods We carried out a cross-sectional study, which included operating room nurses from nine hospitals. Information on socio-demographic characteristics, life-style habits, working activity and psychological attitude of nurses was collected using an anonymous selfadministered structured questionnaire. We evaluated the association of Frequency, Localization and Intensity of LBP (FLI) with qualitative variables making use of the univariate analysis, chi-square test and Fisher's Exact test. Multiple logistic regression analysis was performed to identify the variables that affected the FLI. The covariates included in the model were the variables that had a $\mathrm{p}<0,25$ to the univariate analysis. The significant level was fixed at $\mathrm{p}<0,05$.

Results We studied a total of 185 (60.5\% male) operating room nurses with a mean age of 36,08 $(\mathrm{SD}=7,08)$. The chi-square test showed that FLI is associated with age $(\mathrm{p}=0,042)$, physical activity $(\mathrm{p}=0,036)$, and work-shift $(\mathrm{p}=0,01)$. The logistic regression indicated that age $>35$ years vs. age $<35(\mathrm{OR}=2,68 ; 95 \% \mathrm{CI}=1,17-6,18)$ and diurnal work-shift vs. diurnal/nocturnal $(\mathrm{OR}=4,00 ; 95 \% \mathrm{CI}=1,72-9,0)$ represent risk factors associated to FLI, while physical activity is a protective factor $(\mathrm{OR}=0,47 ; 95 \% \mathrm{CI}=0,20-1,08)$.

Conclusion The data suggest that it is important to promote new programmes of prevention based on professional training and physical activity among nurses and to improve the organisation of work-shift in hospital.

Keywords: low back pain - nurses - operating theatre 


\section{Background}

Chronic disorders of the musculoskeletal system, particularly low back pain (LBP), are increasing and represent a social and economical problem of growing importance due to their detrimental effects on quality of life, mental and physical health, especially if correlated with working conditions (Martinelli et al. 2004).

It has been estimated that in the United States approximately $60-80 \%$ of the adult population has had at least one episode of low back pain in his life. The National Institute of Occupational Safety and Health (NIOSH-USA) classifies it as second among the ten most relevant health problems on the workplace (NIOSH 1997); Low back pain is frequently associated with occupational disability (in particular for people younger than 45 years old) and absence from work (Lee et al. 2001).

According to the Italian Central Institute of Statistics (ISTAT), low back pain is among the most widespread chronic diseases in Italy as well (Proietti et al. 2000). It holds the second position in the list of acute pathologies, just below diseases of the respiratory tract that include syndromes of influenza, and is the primary reason for requesting partial non-fitness for specific work.

All this calls for the employment of great resources in the management of the disease both regarding the days of absence from work, and also regarding insurance expenses.

Despite the spread of the problem, researchers do not propose any kind of classification for low back pain (Walker 2000; Miranda et al. 2002). To date, the term "lumbar rachis disorders" simply indicates the presence of pain in the lumbar region. These disorders are of a multifactorial nature and so many risk factors often concur, sometimes interacting in different ways in each individual (Krause et al. 1998; Heliövara et al. 1991).

Among the working categories with the highest risk of developing this kind of pathologies are healthcare workers and nurses (Martinelli et al. 2004) in particular.

Various studies report association between musculoskeletal disorders, occupational injury, impairment, disability (Klein et al. 1984; Daraiseh et al. 2003; Sherehiy et al. 2004; Karwowski et al. 2005; Karahan et al. 2009) and work-related risk factors for musculoskeletal complaints in the nursing profession. Among work-related risk factors, the physical events like lifting, awkward postures and stooping (Engels et al. 1996; Schenk et al. 2007), are considered the most important sources of this kind of disorders. Moreover the study of biomechanical and psychosocial factors low back pain-related shows a great influence in return to nursing activities determining different levels of disability (Denis et al. 
2007). In particular, biomechanical factors that affect low back pain include weight lifted, task asymmetry, lift rate, load position and reach distances (NIOSH 1997; Davis et al. 2000). There is ample evidence that weight of handled patients is one of the major risk factors for low back injury in nurses in correlation with trunk moment and its axial rotation. These are considered significant risk factors for predicting low back injury (Jang et al. 2007).

The present study investigates the presence of risk factors for musculoskeletal illnesses associated to operating room nursing activities. In this environment, the nurse's professional role regards planning operational assistance to the person undergoing surgery in reply to his needs. This translates into nursing, technical and relational character functions.

In particular the aim of the study was to assess the prevalence of low back pain among operating room nurses and investigate risk factors associated to musculoskeletal injuries in the operating room.

\section{Methods}

\section{Study design and population}

We conduct a cross-sectional study which includes operating room nurses. The research involved hospitals in Rome, randomly selected from all the available hospitals (teaching and general hospitals) in the city. For the selection the complete list of hospitals was used, and the choice of the single hospital was made using a table of random numbers. A total of 9 hospitals (2 teaching and 7 general hospitals) were selected and 225 operating room nurses were recruited into the study. Nurses who were absent from work during the study period were excluded.

Information on socio-demographic characteristics, life-style habits (such as smoking, physical activity), BMI, working activity and psychological attitude of nurses were collected using an anonymous self-administered structured questionnaire. Previously we carried out a pilot study using 20 nurses to assess the goodness of the questionnaire and to standardize the method of data collection. Data relative to pilot study were not included in the present study.

Data collection was performed between June and September 2007, one month for each hospital. 


\section{Questionnaire}

In order to investigate the nurses' working load we structured a questionnaire composed of 63 items grouped into 5 broad theme groups: general data, general work activity, specific work activity in operating theatre, musculoskeletal disorders, psychological attitude. The items referred to load handling, effective amount of working hours, work shifts and activities in surgery ward (different wards involve different working risks for low back pain), type of surgery (elective or urgent/emergency), posture assumed by nurses during work and personal perception of risk for low back pain (such as transferring patient from bed to operating table, surgical material storage). We also considered other variables such as having worked in other wards, life habits, taking part in a manual handling of loads (MHL) course. To evaluate musculoskeletal injuries we asked nurses if they filled low back pain in the last 12 months, their perception and intensity of pain, localization of pain and the frequency of such accidents. We used the criteria suggested by Quebec Task Force to assess the severity of pain and the Quebec Scale Disability to assess the level of functional disability. Psychological attitude was investigated with a part of OREGE (Outil de Repérage e de Evaluation des GEstes) questionnaire.

\section{Statistical analysis}

Results are presented as mean \pm Standard Deviation $(\mathrm{SD})$ for the quantitative variables. We evaluated three outcomes: acute event of LBP that needed rest in bed (dichotomy variable), renunciation to pleasant activities (dichotomy variable) and Intensity of LBP (estimated using VAS scale).

Univariate Analysis (Chi-square and Fisher's Exact Tests for qualitative variables; t-Test and Mann-Whitney Test for quantitative variables) were performed to evaluate the statistic associations between the three studied outcomes and covariates.

The models of multivariate regression (one for each different outcome) were built to assess the influence of independent variables on three outcomes and the Odds Ratio (OR) have been computed with respective Confidence Interval at level 95\% (CI95\%). We reported into models only variables with a p-value less than 0,25 to the univariate analysis, adjusting for gender and age (24). The good of fitness of the model was evaluated with HosmerLemeshow Test for the logistic regression model, and $\mathrm{R}^{2}$ for linear regression model. Moreover, the LBP episode's frequency (dichotomy variable: at list one episode per week vs. 
less than one episode per week) and pain localization (mono vs. multiple-localization) were used to adjust the multivariate regression linear model built for intensity outcome.

The statistical significance was fixed at $\mathrm{p}<0,05$.

The data were analysed using SPSS 12.0 software for Windows.

\section{Results}

We administered the questionnaire to 225 nurses; the response rate was $82.2 \%$, in fact 185 nurses (60,5\% males) accepted to participate in the study. The mean (SD) of age was 36,08 (7.08) years old. The mean (SD) of BMI was 22,60 $(3,21)$ and 25,50 $(3,75)$ respectively for males and females. $57,8 \%$ of nurses hadn't got sons, $62,2 \%$ didn't work the night and $56,2 \%$ didn't smoke.

Acute events of LBP were reported by 32 nurses (17.3\%) and renunciation to pleasant activities due to LBP by 83 nurses $(44.9 \%)$.

Tables 1 and 2 showed respectively the results of the univariate analysis and multivariate analysis.

It can be seen (table 1) that the presence of diurnal work shift is associated with the occurrence of acute events ( $81,3 \%$ vs. $58,2 \%$; $\mathrm{p}=0,014)$; while renunciation to pleasant activities occurs more often in people over 35 years $(\mathrm{p}=0,002)$, in nurses practicing no physical activity $(\mathrm{p}=0,029)$, with more years of work $(\mathrm{p}=0,037)$ and working not in the operating theatre $(\mathrm{p}=0,014)$; and the intensity of LBP is associated with not practising physical activity $(\mathrm{p}=0,016)$ and working not in the operating theatre $(\mathrm{p}=0,042)$.

As regards multivariate analysis, the variable significantly associated to the outcome acute event was diurnal work-shift vs. diurnal/nocturnal $(\mathrm{OR}=0,30 ; 95 \% \mathrm{CI}=0,12-0,78)$ (HosmerLemeshow Test for the goodness of fit of the model: $\mathrm{p}=0,9$ ).

The covariates significantly associated to the second outcome, renunciation to pleasant activities, were: work only in operating theatre $(\mathrm{OR}=0,45 ; 95 \% \mathrm{CI}=0,23-0,88)$, physical activity $(\mathrm{OR}=0,48 ; 95 \% \mathrm{CI}=0,26-0,89)$ and age $>35$ years vs. age $<35(\mathrm{OR}=2,64$; 95\% CI=1,42-4,89) (Table 2) (Hosmer-Lemeshow Test for the goodness of fit of the model: $\mathrm{p}=0,6$ ).

The covariates significantly associated to the intensity of LBP, were frequency of LBP $(\beta=0,651 ; \mathrm{p}=0,028)$ and multiple-localization $(\beta=0,648 ; \mathrm{p}=0,034)$ (Table 2). The $\mathrm{R}^{2}$ coefficient, for the goodness of the model, was 0,09 . 


\section{Discussion}

Acute events and renunciation to pleasant activities due to LBP were present in one sixth and almost half of participants of the survey, demonstrating LBP is a concrete issue in our crosssectional study, confirming data from the international literature.

The analysis showed that diurnal work-shift significantly increased the risk of acute event of LBP, confirming the results of previous studies (Krause et al. 1998; Lorusso et al. 2007). Practicing physical activity, as demonstrated by Bordini et al. (1999), and working only in operating theatre reduced the risk of renunciation to pleasant activities, while older age is associated to increase of the risk, as reported by Miranda et al. (2002). The frequency of LBP more than once per week and the multiple-localization of LBP were appreciably associated to intensity of LBP.

It is necessary to identify the most important risk factors to obtain effective preventive intervention.

Among risk factors there are: constitutional aspects, although there are studies that have not brought to light a different incidence among the control groups (Cushway et al. 1929). These factors include: age (Miranda et al. 2002), female gender (Brini et al. 2005), height (with a greater risk factor in tall individuals) (Mandal 1984), the dimensions of the spinal canal (with a greater risk factor for individuals with a narrow canal) and the individual's genetic characteristics (Spitzer et al. 1987).

Another category of risk factors regards lifestyle: smoking (studies have indicated its enormous dimension) (Leboeuf-Yde 2000), sedentary lifestyle (Bordini et al. 1999) (physical exercise is considered to be a protecting factor, but it has to be carried out at least twice a week on a regular basis), obesity (Troussier et al. 1994) (it might represent a risk although there is not sufficient evidence to determine whether there is a relation between body weight and backache) (Leboeuf-Yde 2000) and stress (Miranda et al. 2002; Boos et al. 2002; Linton 2000).

Other risk factors can also be associated to the ones present on the workplace such as: psychosocial stress factors, length of employment, organizational conditions, work-shifts, overtime, breaks, decision-making freedom, psychological pressure and dissatisfaction (Krause et al. 1998; Lorusso et al. 2007). Among these are assuming particular postures 
(O'Sullivan et al. 2002), though this aspect is not considered a risk for the bone, muscular and articular apparatus by the Legislative Decree 81/08 (Decreto legislativo 81/08), but when these postures are incorrect (Colombini et al. 1995) they may induce a sense of discomfort, fatigue and pain in a matter of a short term. A greater degeneration of the entire lumbar rachis, and particularly of the lower lumbar region, is also correlated to the handling of loads with frequent lifting, pushing and tractions, especially in absence of mechanical devices (Karahan et al. 2009).

During their activities, nursing personnel are exposed to various kinds of risks: biological risks, pathologies linked to allergies, chemical risks because of environmental smog produced by anaesthetic gas and by the numerous categories of detergents and disinfectants in use (ISPESL 2005), the physical risk of using ionizing radiation (Motta et al. 2000) required in some forms of surgery and X-ray machinery among the many other electrical apparatus used in the operating room.

Nurses are also exposed to a risk of lower back pain. The first strategy set out by Decree $81 / 08$ to limit risks inherent to load handling is that of automating the process. Automation does not prove to be practical in healthcare facilities where patients have to be moved.

Ergonomic intervention, even if more difficult, represents a permanent preventive action and doesn't need that worker respects behavioural rules (Capodaglio et al. 2001).

Today Health system requests increase of pace of the work (business organization, to set up system of DRG) and diurnals work shifts increase risk for low back pain and acute event, therefore we suggest to reorganize the management of the work system in order that nurses carry out a work schedule correctly, and this particularly in relation to the definition of appropriate time schedule and sustainable workload (Damiani et al. 2006). Because of the intense work shifts we didn't observed expected improvements also in health care workers that attend a course of handling of loads.

In conclusion, according to our results, it emerges clearly the need of both encouraging the attendance to course of handling of loads as suggest in Legislative Decree 81/08, and of considering physical activity not only as a simple lifestyle, but a real way in reducing the occurrence of LBP in this professional category. Data analysis shows the importance of physical activity as protective factor against the increase of risk for low back pain and a possible suggestion could be organizing a specific training for health personnel working in operating theatres. Physical activity programmes among healthcare professional workers could be intended mandatory for preventing LBP, and this activity could be intended as a part 
of a disability management programme, as reported by the National Institute of Disability Management and Research (2006). In order to verify the protective effect of such an intervention, a randomized clinical trial among nurses who work in operating theatre needs to be conducted after those preventive interventions, that mainly deals with organizational and ergonomic aspects, have been carried out.

Conflict of Interest: There is no conflict of interest. 


\section{References}

Boos N, Semmer N, Elfering A, Schade V, Gal I, Zanetti M, Kissling R, Buchegger N, Hodler J, Main CJ (2000) Natural history of individuals with asymptomatic disc abnormalities in magnetic resonance imaging: predictors of low back pain-related medical consultation and work incapacity. Spine 25(12):1484-92

Bordini L, De Vito G, Molteni G, Boccardi S (1999) The epidemiology of musculoskeletal changes due to biomechanical overload of the spine in the manual lifting of patients Med Lav 90(2):103-16

Brini S, Migliori R, Cormons V, Giatti A, Manigrasso V (2005) Il mal di schiena negli operatori sanitari: diffusione del fenomeno, livelli di rischio, prevenzione e trattamento (Low back pain in health personnel: spread of the issue, risk levels, prevention and treatment). Centro Studi Evidence $\quad$ Based Nursing. Available at http://www.evidencebasednursing.it/revisioni/lavoriCS/02_C_schiena.pdf, 30 September 05. Capodaglio EM, Facioli M, Bazzini G (2001) Evaluation of the risk related to repetitive work activities: testing of several methods proposed in the literature. G Ital Med Lav Ergon 23(4):467-76

Colombini D, Occhipinti E, Molteni G, Grieco A, Pedotti A, Boccardi S, Frigo C, Menoni O (1985) Posture Analysis. Ergonomics 28:275-84

Cushway BC, Mailer RJ (1929) Routine examination of the spine for industrial employees. J.A.M.A 92:701-5

Damiani G, Federico B, Pinnarelli L, Sammarco A, Ricciardi W (2006) Evaluating the effect of stress management programmes at the work-site on absenteeism reduction: a systematic review. Ital J Public Health 2: 38-43

Daraiseh N, Genaidy AM, Karwowski W, Davis LS, Stambough J, Huston RI (2003) Musculoskeletal outcomes in multiple body regions and work effects among nurses: the effects of stressful and stimulating working conditions. Ergonomics 46:1178-99

Davis KG, Marras WS. (2000) The effects of motion on trunk biomechanics. Clinical Biomechanics 15:703-17

Decreto Legislativo del 9 aprile 2008 , n. 81 “Attuazione dell'articolo 1 della legge 3 agosto 2007, n. 123, in materia di tutela della salute e della sicurezza nei luoghi di lavoro" (Legislative 
Decree 81/08 - Implementation of art. 1, law 3 August, 2005, n. 123, concerning health and

Denis S, Shannon HS, Wessel J, Stratford P, Weller I (2007) Association of Low Back Pain, Impairment, Disability \& Work Limitations in Nurses. J Occup Rehabil 17:213-26

Engels JA, Van Der Gulden JWJ, Senden TF, van't Hof B (1996) Work related risk factors for musculoskeletal complaints in the nursing profession: results of a questionnaire survey. Occupational and Environmental Medicine 53:636-41

Heliövara M, Mäkelä M, Knekt P, Impivaara O, Aromaa A (1991) Determinants of sciatica and low-back pain. Spine 16(6):608-3

ISPESL. Il reparto operatorio e le linee guida ISPESL (The operating theathre and the ISPESL guidelines ). Roma. Available at URL: http://www.ispesl.it 30 July, 2005

Jang R, Karwowski W, Quesadax PM, Rodrick D, Sherehiy B, Cronin SN, Layer JK (2007) Biomechanical evaluation of nursing tasks in a hospital setting. Ergonomics 50(11):1835-55

Karahan A, Kav S, Abbasoglu A, Dogan N (2009) Low back pain: prevalence and associated risk factors among hospital staff. J Adv Nurs 65(3):516-24

Karwowski W, Ren-liu J, Rodrick D, Quesada PM, Cronin SN (2005) Self-evaluation of biomechanical task demands, work environment and perceived risk of injury by nurses: a field study. Occup Ergonomics 5:13-27

Klein BP, Jenson RC, Sandstrom LM (1984) Assessment of workers' compensation claims for back strains/sprains. J Occup Med 26:443-8

Krause N, Ragland DR, Fischer JM, Syme SL (1998) Volvo Award Winner in Clinical Studies, Psychosocial Job Factors, Physical Workload, and Incidence of Work-Related Spinal Injury: A 5-Year Prospective Study of Urban Transit Operators. Spine 23(23):2507-16

Leboeuf-Yde C (2000) Body Weight and Low Back Pain, A Systematic Literature Review of 56 Journal Articles Reporting on 65 Epidemiologic Studies. Spine 25(2):226-37

Lee P, Helewa A, Goldsmith CH, Smythe HA, Stitt LW (2001) Low back pain: prevalence and risk factors in an industrial setting. J Rheumatol 28:346-51

Linton SJ (2000) A review of psychological Risk Factors in Back and Neck Pain. Spine 25(9):1148-56

Lorusso A, Bruno S, L'Abbate N (2007) A review of Low Back Pain and Musculoskeletal Disorders among Italian Nursing Personnel. Ind Health 45:637-44

Mandal AC (1984) The correct height of school furniture. Physiotherapy 70(2):48-53

Marras WS, Karwowski W (2006) Interventions, Controls, and Applications in Occupational Ergonomics. CRC Press, Boca Raton 
Martinelli S, Artioli G, Vinceti M, Bergomi M, Bussolanti N, Camellini R, Celotti P, Capelli P, Roccato L, Gobba F (2004) Low back pain risk in nurses and its prevention. Prof Inferm 57(4):238-42

Miranda H, Viikari-Juntura E, Martikainen R, Takala EP, Riihimäki H (2002) Individual Factors, Occupational Loading, and Physical Exercise as Predictors of Sciatic Pain. Spine 27(10):1102-9

Motta C, Turra A, Farina B (2000) Radioguided surgery of breast cancer: radiation protection survey. Tumori 86(4):372-4

National Institute of Disability Management and Research (2006) Disability management in a global context. Adelaide, September 27, 2006. Available at URL: www.workcover.com/documents.aspx? fno $=1347$

NIOSH (1997) Musculoskeletal Disorders and Workplace Factors. A critical Review of Epidemiologic Evidence for Work-Related Musculoskeletal Disorders of the Neck, Upper Extremity, and Low Back. US, Department of Health and Human Services Publication $\mathrm{n}^{\circ}$ 97141 July 1997.

O'Sullivan PB, Grahamslaw KM, Kendell M, Lapenskie SC, Möller NE, Richards KV (2002) The Effect of Different Standing and Sitting Postures on Trunk Muscle Activity in a Pain-Free Population. Spine 27(11):1238-44

Proietti L, Duscio D, Rotiroti G, Sandonà PB (2000)Environmental monitoring and health monitoring for personnel exposed to inhalation anesthetics. G Ital Med Lav Ergon 22(2):130-4

Schenk P, Läubli T, Hodler J, Klipstein A. (2007) Symptomatology of recurrent low back pain in nursing and administrative professions. Eur Spine J 16:1789-98

Sherehiy B, Karwowski W, Marek T (2004) Relationship between risk factors and musculoskeletal disorders in the nursing profession: a systematic review. Occup Ergonomics 4:241-79

Spitzer WO, LeBlanc FE, Dupuis M (1987) Scientific approach to the assessment and management of activity-related spinal disorders. A monograph for clinicians. Report of the Quebec Task Force on Spinal Disorders. Spine 12(7s):1-59

Troussier B, Davoine P, de Gaudemaris R, Fauconnier J, Phelip X. (1994) Back pain in school children. A study among 1178 pupils. Scand J Rehab Med 26:143-6

Walker BF (2000) The prevalence of low back pain: a systematic review of the literature from 1966 to 1998. J Spinal Disorders 13(3):205-17 
Table 2. Multivariate regressions for the dependent variables: acute event. renunciation to pleasant activities and intensity of LBP.

\begin{tabular}{|c|c|c|c|c|c|c|c|}
\hline \multirow[t]{3}{*}{ Covariates } & & \multicolumn{2}{|c|}{$\begin{array}{c}\text { Acute event } \\
(\text { Yes/No) * }\end{array}$} & \multicolumn{2}{|c|}{$\begin{array}{c}\text { Renunciation to } \\
\text { pleasant activities } \\
(\text { Yes/No)* }\end{array}$} & \multicolumn{2}{|c|}{$\begin{array}{l}\text { Intensity } \\
\text { of LBP ** }\end{array}$} \\
\hline & & OR & $95 \% \mathrm{Cl}$ & OR & $95 \% \mathrm{Cl}$ & beta & $\mathrm{p}$ \\
\hline & & & low upp & & low upp & & \\
\hline Gender & $\begin{array}{l}M \\
F\end{array}$ & $\begin{array}{l}1.00 \\
1.30\end{array}$ & n.s. & $\begin{array}{l}1.00 \\
0.60\end{array}$ & n.s. & -0.17 & n.s. \\
\hline Age (years) & $\begin{array}{r}<=35 \\
>35 \\
\end{array}$ & $\begin{array}{l}1.00 \\
0.76 \\
\end{array}$ & n.s. & $\begin{array}{l}1.00 \\
2.64 \\
\end{array}$ & $1.42 \quad 4.89$ & 0.12 & n.s. \\
\hline Sons & $\begin{array}{l}\mathrm{No}^{\circ} \\
\text { Yes }\end{array}$ & a & & $\begin{array}{l}1.00 \\
1.24\end{array}$ & n.s. & \multicolumn{2}{|l|}{$a$} \\
\hline Physical Activity & $\begin{array}{l}\mathrm{No}^{\circ} \\
\mathrm{Yes} \\
\end{array}$ & $\begin{array}{l}1.00 \\
0.66 \\
\end{array}$ & n.s. & $\begin{array}{l}1.00 \\
0.48 \\
\end{array}$ & $0.26 \quad 0.89$ & -0.50 & n.s. \\
\hline Smoking habits & $\begin{array}{r}\mathrm{No}^{\circ} \\
\text { Yes/former }\end{array}$ & a & & a & & 0.11 & n.s. \\
\hline Years of work & $\begin{array}{r}<=4^{\circ} \\
>4 \\
\end{array}$ & $\begin{array}{l}1.00 \\
5.68 \\
\end{array}$ & n.s. & $\begin{array}{l}1.00 \\
2.31 \\
\end{array}$ & n.s. & \multicolumn{2}{|l|}{ a } \\
\hline $\begin{array}{l}\text { Work only in } \\
\text { Operating Theatre }\end{array}$ & $\begin{aligned} \mathrm{No}^{\circ} \\
\text { Yes }\end{aligned}$ & \multicolumn{2}{|l|}{ a } & $\begin{array}{l}1.00 \\
0.45\end{array}$ & $0.23 \quad 0.88$ & \multicolumn{2}{|l|}{-0.53} \\
\hline Work Shift & $\begin{array}{r}\text { Diurnals }^{\circ} \\
\text { Diurnals/nocturnals } \\
\end{array}$ & $\begin{array}{l}1.00 \\
0.30 \\
\end{array}$ & $0.12 \quad 0.78$ & \multicolumn{2}{|l|}{ a } & \multicolumn{2}{|c|}{-0.32 n.s. } \\
\hline $\begin{array}{l}\text { Kind of the } \\
\text { Operating Theatre }\end{array}$ & $\begin{array}{r}\text { One type of specialistic } \\
\text { surgery } \\
\text { All types of surgeries }\end{array}$ & \multicolumn{2}{|r|}{$0.15 \quad 0.10$} & \multicolumn{2}{|l|}{ a } & \multicolumn{2}{|c|}{$0.0 \mathrm{~s} \quad \mathrm{~N}$} \\
\hline $\begin{array}{l}\text { Course of } \\
\text { handling of loads }\end{array}$ & $\begin{aligned} & \text { No } \\
& \text { Yes }\end{aligned}$ & \multicolumn{2}{|l|}{ a } & \multicolumn{2}{|l|}{ a } & \multicolumn{2}{|l|}{$\mathrm{a}$} \\
\hline $\begin{array}{l}\text { Nurse's role in } \\
\text { Operating Theatre }\end{array}$ & $\begin{array}{r}\text { Circulating nurse }^{\circ} \\
\text { Scrub nurse }\end{array}$ & \multicolumn{2}{|l|}{ a } & \multicolumn{2}{|l|}{ a } & \multicolumn{2}{|l|}{ a } \\
\hline Frequency of LBP & $\begin{array}{l}<\text { <nce a week } \\
\geq \text { once a week }\end{array}$ & \multicolumn{2}{|l|}{ - } & \multicolumn{2}{|l|}{-} & 0.65 & 0.03 \\
\hline \multirow[t]{2}{*}{ Localization } & $\begin{array}{r}\text { monolocalization }^{\circ} \\
\text { plurilocalization }\end{array}$ & \multirow{2}{*}{\multicolumn{2}{|c|}{$0.97^{\wedge \wedge}$}} & \multicolumn{2}{|r|}{ 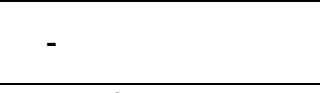 } & \multirow{2}{*}{\multicolumn{2}{|c|}{$\frac{0.650 .03}{0.09^{\wedge}}$}} \\
\hline & & & & & $0.55^{\wedge \wedge}$ & & \\
\hline
\end{tabular}

\footnotetext{
* Logistic Regression Model

** Linear Regression Model

$\wedge$ Coefficient $\mathrm{R}^{2}$

$\wedge \wedge$ p-value Hosmer-Lemeshow's Test

- No in the model

$\circ$ reference

n.s. not statistically significant

a Variables not in the model (p-value $>0.25$ at the Univariate Analysis)
} 
Table 1. Univariate analysis for the dependent variables: acute event. renunciation to pleasant activities and intensity.

\begin{tabular}{|c|c|c|c|c|c|c|c|c|c|c|c|c|c|c|}
\hline \multirow{3}{*}{\multicolumn{2}{|c|}{ Variables }} & \multicolumn{5}{|c|}{ Acute event } & \multicolumn{5}{|c|}{ Renunciation to pleasant activities } & \multicolumn{3}{|c|}{ Intensity of LBP } \\
\hline & & \multicolumn{2}{|c|}{ No } & \multicolumn{2}{|c|}{ Yes } & \multirow[b]{2}{*}{$p^{\wedge}$} & \multicolumn{2}{|c|}{ No } & \multicolumn{2}{|c|}{ Yes } & \multirow[b]{2}{*}{$p^{\wedge}$} & & & \multirow[b]{2}{*}{$\mathrm{p}^{\circ}$} \\
\hline & & $\mathrm{N}$ & $\%$ & $\mathrm{~N}$ & $\%$ & & $\mathrm{~N}$ & $\%$ & $\mathrm{~N}$ & $\%$ & & $\mathrm{~N}$ & mean $\pm S D$ & \\
\hline \multirow[t]{2}{*}{ Gender } & M & 93 & 60.8 & 19 & 59.4 & 0.882 & 58 & 56.9 & 54 & 65.1 & 0.257 & 107 & $6.4 \pm 1.8$ & 0.248 \\
\hline & $\mathrm{F}$ & 60 & 39.2 & 13 & 40.6 & & 44 & 43.1 & 29 & 34.9 & & 69 & $6.1 \pm 1.9$ & \\
\hline \multirow[t]{2}{*}{ Age (years) } & $<=35$ & 82 & 53.6 & 17 & 53.1 & 0.961 & 65 & 63.7 & 34 & 41 & 0.002 & 93 & $6.2 \pm 1.8$ & 0.513 \\
\hline & $>35$ & 71 & 46.4 & 15 & 46.9 & & 37 & 36.3 & 49 & 59 & & 83 & $6.4 \pm 1.9$ & \\
\hline \multirow[t]{2}{*}{ Sons } & No & 91 & 59.5 & 16 & 50 & 0.324 & 65 & 63.7 & 42 & 50.6 & 0.072 & 100 & $6.2 \pm 1.8$ & 0.587 \\
\hline & Yes & 62 & 40.5 & 16 & 50 & & 37 & 36.3 & 41 & 49.4 & & 76 & $6.4 \pm 2.0$ & \\
\hline \multirow[t]{2}{*}{ Physical Activity } & No & 75 & 49 & 20 & 62.5 & 0.165 & 45 & 44.1 & 50 & 60.2 & 0.029 & 93 & $6.6 \pm 1.8$ & 0.016 \\
\hline & Yes & 78 & 51 & 12 & 37.5 & & 57 & 55.9 & 33 & 39.8 & & 83 & $5.9 \pm 2.0$ & \\
\hline \multirow[t]{2}{*}{ Smoking habits } & No & 87 & 56.9 & 17 & 53.1 & 0.698 & 58 & 56.9 & 46 & 55.4 & 0.844 & 98 & $6.1 \pm 1.9$ & 0.192 \\
\hline & Yes/former & 66 & 43.1 & 15 & 46.9 & & 44 & 43.1 & 37 & 44.6 & & 78 & $6.5 \pm 1.9$ & \\
\hline \multirow[t]{2}{*}{ Years of work } & $<=4$ & 20 & 13.1 & 1 & 3.2 & 0.116 & 16 & 15.8 & 5 & 6 & 0.037 & 19 & $6.1 \pm 1.8$ & 0.996 \\
\hline & $>4$ & 133 & 86.9 & 30 & 96.8 & & 85 & 84.2 & 78 & 94 & & 156 & $6.3 \pm 1.9$ & \\
\hline \multirow[t]{2}{*}{$\begin{array}{l}\text { Work only in } \\
\text { Operating Theatre }\end{array}$} & No & 102 & 66.7 & 21 & 65.6 & 0.91 & 60 & 58.8 & 63 & 75.9 & 0.014 & 116 & $6.5 \pm 2.0$ & 0.042 \\
\hline & Yes & 51 & 33.3 & 11 & 34.4 & & 42 & 41.2 & 20 & 24.1 & & 60 & $5.9 \pm 1.7$ & \\
\hline \multirow[t]{2}{*}{ Work Shift } & Diurnals & 89 & 58.2 & 26 & 81.3 & 0.014 & 66 & 64.7 & 49 & 59 & 0.429 & 110 & $6.5 \pm 1.8$ & 0.133 \\
\hline & Diurnals/nocturnals & 64 & 41.8 & 6 & 18.8 & & 36 & 35.3 & 34 & 41 & & 66 & $6.0 \pm 2.1$ & \\
\hline \multirow[t]{2}{*}{$\begin{array}{l}\text { Kind of the } \\
\text { Operating Theatre }\end{array}$} & $\begin{array}{l}\text { Only type of } \\
\text { specialistic surgery } \\
\text { All types of }\end{array}$ & 73 & 47.7 & 18 & 56.3 & 0.38 & 50 & 49 & 41 & 49.4 & 0.959 & 87 & $6.1 \pm 1.9$ & 0.305 \\
\hline & $\begin{array}{r}\text { All ypes of } \\
\text { surgeries } \\
\end{array}$ & 80 & 52.3 & 14 & 43.8 & & 52 & 51 & 42 & 50.6 & & 89 & $6.4 \pm 1.9$ & \\
\hline \multirow[t]{2}{*}{$\begin{array}{l}\text { Course of handling } \\
\text { of loads }\end{array}$} & No & 105 & 68.6 & 22 & 68.8 & 0.989 & 72 & 70.6 & 55 & 66.3 & 0.528 & 121 & $6.3 \pm 1.9$ & 0.913 \\
\hline & Yes & 48 & 31.4 & 10 & 31.3 & & 30 & 29.4 & 28 & 33.7 & & 55 & $6.3 \pm 1.8$ & \\
\hline \multirow[t]{2}{*}{$\begin{array}{l}\text { Nurse's role in } \\
\text { Operating Theatre }\end{array}$} & Circulating nurse & 72 & 47.1 & 16 & 50 & 0.762 & 52 & 51 & 36 & 43.4 & 0.303 & 83 & $6.4 \pm 2.0$ & 0.464 \\
\hline & Scrub nurse & 81 & 52.9 & 16 & 50 & & 50 & 49 & 47 & 56.6 & & 93 & $6.2 \pm 1.8$ & \\
\hline
\end{tabular}

${ }^{\wedge} \mathrm{p}$-value of Chi-square test or Exact Fisher test

${ }^{\circ} \mathrm{p}$-value of $\mathrm{t}$-test or Mann-Whitney 

Answers to reviewer 1

We made the changes requested, i.e.:

In the third section of "Results" (p. 6, line 29 -40), we corrected the orthographic mistakes:

- line 31/32: vs must be vs.;

- $p=0,014$ instead than $p=00,14$

- Moreover, we used the same spelling in the whole text for the "p" values: XXX=XXX (without blanks before and after the "=")

Many thanks for the opportunity to consider our work for publication on the Journal of Public Health 